\title{
NOW IS THE TIME FOR FEMINIST CRITICISM: A Review of Asinamali!
}

\author{
Carol Steinberg
}

\section{Introduction}

South African drama of the 1980s is characterized by its powerful and creative attack on apartheid. In a time in which the voices of many black South Africans were silenced through the banning of their political organizations, drama became a crucial means of public political expression.

The political role of anti-apartheid drama cannot be underestimated. During the difficult years of its performance it was perhaps inappropriate to criticize it. In the face of the harsh conditions of theatre production, the ever-vigilant censors, and the detention and assassination of theatre workers, the imperative of progressive drama critics was to encourage anti-apartheid drama almost unequivocally.

One of the most renowned genres, or subgenres, of anti-apartheid drama is the minimalist protest/resistance theatre that reached a peak during the early to mid-1980s. This subgenre may be defined by its workshop method of production; its all black male cast; its minimalist sets and costume; its high-energy performance using song, dance and mime; its use of the images of the South Africa of the eighties: the freedom song, the slogans, the toyi-toyi, the necklace, the Albert Street queue, etc. These plays took as their themes the hardships that black South Africans suffer under apartheid and their resistance to it. Plays like Woza Albert, Asinamali!, Bopha and worker plays like The Long March form part of this subgenre. ${ }^{1}$

In the early 1990s apartheid is by no means dead and repression continues, but the post 2 February 1990 era undoubtedly extends the space in which cultural activists can think and work. Albie Sachs's recent controversial intervention articulates and argues for this space. ${ }^{2}$ 
It is time to interrogate a canon which many of us hold very dear: anti-apartheid theatre. It has always been incumbent on feminist cultural critics to interrogate their own canon. A revisionary criticism of the gender ideology of the Anglo-American canon forms a significant component of the feminist critical tradition. While South African drama critics move away from 'solidarity criticism', it is time for feminist drama critics in particular to refuse the notion of a genderless class and race subjectivity.

The position I argue in this instance is a 'weak' one in terms of feminist cultural criticism. Via an analysis of Mbongeni Ngema's ${ }^{3}$ Asinamali! (1986), I will attempt to demonstrate that the gender ideology of the play detracts from its imperative to mobilize against racism. I will not argue that the play should address women's issues and struggles directly, but simply that its gender ideology undermines its motive force - the struggle against apartheid, and that to this extent, the play fails in its own terms.

While I recognize that sexual oppression has a material existence that cannot be reduced to an ancillary of other forms of oppression, I am not prepared to assert that all plays should directly address women's issues. Sexual oppression must be fought concurrently with other struggles, but this does not translate into the contention that all plays, books and films must address sexual oppression.

In the dramatic world of Asinamali! a bold line is drawn between 'us' and 'them': those audience members who share the life experiences and world view of the five central characters and those who don't. This dynamic 'sustain(s) different and conflicting [actor-audience] relationships within a single audience simultaneously' (Banning, 1989: 193). It is on this actor-audience relationship that my paper will focus. Like the other plays in its genre, one of Asinamali!'s primary imperatives is the mobilization of the 'us' members of the audience against racial, and to a lesser extent, class oppression. If, as I will argue, the play delimits the 'us' audience members to an exclusive group of black men, then black women are alienated and excluded. By relegating black women to the 'them' category of whites and informers, the play reduces the target of its mobilizatory force, thereby undermining its antiracist imperative. ${ }^{4}$

\section{Background to Asinamali!}

A new phase of resistance to apartheid began in 1984 with an explosion of mass anger erupting in the townships of the Vaal Triangle. Residents marched in opposition to rent increases. There were physical attacks on the community councillors responsible, and some were killed. The uprisings soon spread around the country. The state responded with increased repression. It is in this context of political turmoil and mass uprisings that Asinamali! was created: 
Out of the anger and passion of the residents of the Lamontville township came the leader Msizi Dube. Passionately demonstrating against proposed rent increases, he led the masses with the cry 'Asinamali!' - 'We have no money!' This rallying phrase provided a focus for the disenfranchised as well as a poignant description of the conditions of Blacks throughout South Africa. (Ndlovu, 1986: 179).

Asinamali! was first performed at the Market Theatre ${ }^{5}$ in 1985 . The play is set in a South African gaol. The five black male protagonists recount their personal stories through word, song and dance, describing the events that brought them to Durban Central Prison. Bongani is a migrant labourer who has killed his girlfriend; Thami is a farm labourer who was seduced by his white employer's wife and convicted under the Immorality Act; Bhoyi is an activist who worked with Msizi Dube; Solomzi is a petty gangster who pickpockets at mass funerals and demonstrations; Bheki is unfairly convicted of political crimes after a police raid on the house of his common-law wife and her activist son.

\section{Us and them: black and white}

A burst of sound and energy opens the play: five black men chant a rhythmic song in Zulu. The men chant and sway in unison, establishing a powerful visual and auditory image of collectivity. Their sense of brotherhood is sustained throughout the play. They share a home (the prison cell) where they eat, sleep and wash together; they are dressed in identical khaki uniforms; and they are subject to the will of the same authority figures (the prison warders). They are brothers in a hostile world.

The opening song is interrupted by Bheki who jumps up to deliver the first testimony of the play:

I come from Zululand. I got a place to stay in Lamontville township, near the white city of Durban. During that time this man (he points to his $T$-shirt which has the picture of a man) Msizi Dube, a very strong leader and a powerful voice for our people, was killed. They killed him. The government spies killed him. The reason for his death was that he maintained that we have no money. A-SI-NA-MA-LI! so we cannot afford to pay the government's high rent increase. People took up this call:

'AAASSSIIINNNAAA MMMAAALLLIII!' and the police went to work. Many of us died and many of us went to jail, and it is still happening now. (Ngema, 1986: 182)

Bheki's speech serves, on one level, as the linguistic equivalent of the opening image. His personal ' $\mathrm{I}$ ' is subsumed by the collective 'we' (1986: 192) so that his character acquires a communal identity. This raises an immediate question, one that is asked and answered throughout the course of the play: who belongs to the collective 'we', to the family, and who belongs to the implied other category, 'you'? 


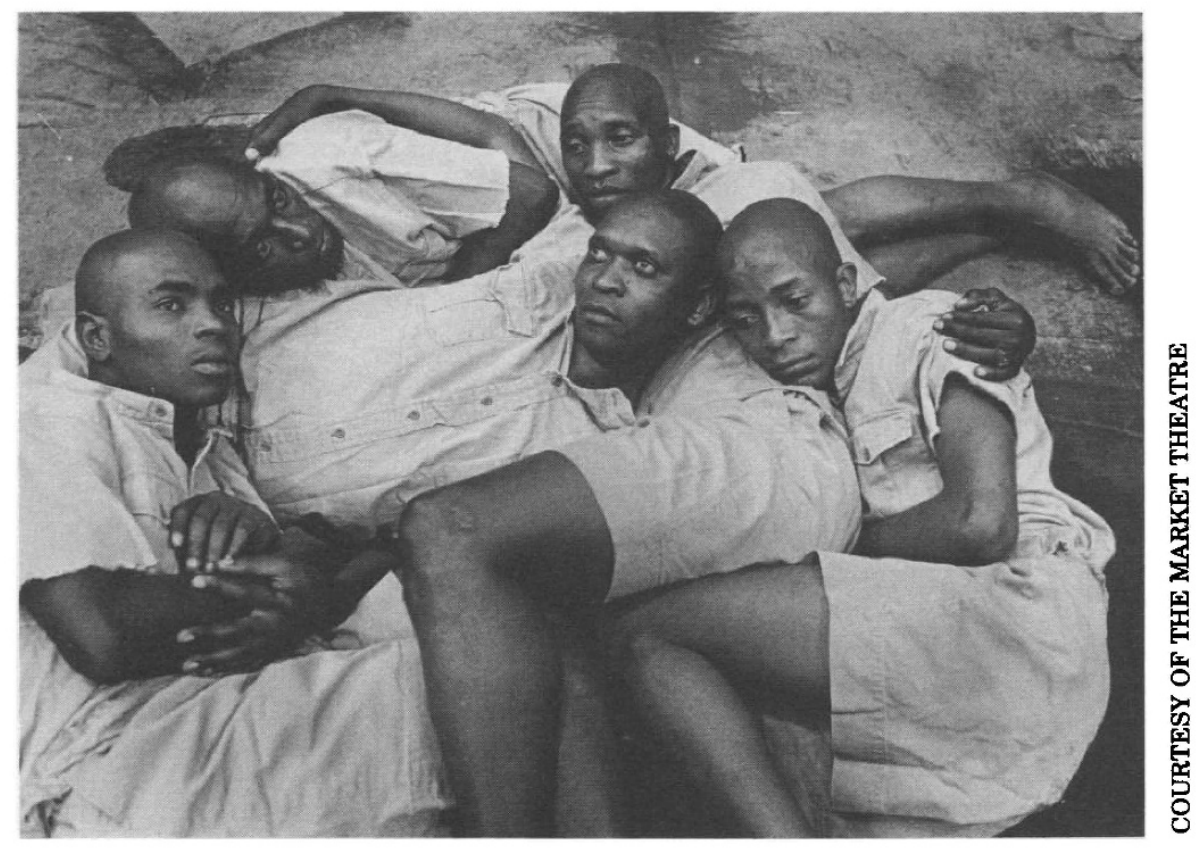

Most pertinent to this and to my analysis of the play's actoraudience relationships is the antinaturalist style that Asinamali! adopts in relation to its audience. In the theatre there is no aesthetic closure around the text, separating it from its conditions of performance. In Asinamali! this is particularly germane - the audience is a protagonist, an important element in the production of meaning. The play is not an hermetic world into which the audience voyeuristically peeps; the actors draw the audience into the world of the play. When one of the characters re-enacts his life story, he is addressing both the on-stage audience (the four interlocutors) and its extension - the audience in the auditorium. The audience on stage guides the responses of the audience proper. The actors often address the audience directly, particularly when they break the narrative with song. At no point does the play slip into the naturalist mode of pretending that there is no audience, that the action is a slice of life. The actors tell stories within the story and the play delights in its own theatricality. In this context 'we' and 'you' is addressed to the audience. In using these words, the actor is defining an identity for the audience who, in turn, will place themselves in one of the two categories according to their extra-theatrical experiences.

Although the play was created by black South Africans under the direction of Mbongeni Ngema, it was controlled economically by the Market Theatre. Asinamali?'s commercial première was at the Market Theatre after having been performed in the townships around the 
Zululand area. Hence the play must have anticipated a multiracial audience from the outset. Yvonne Banning notes that, unlike a play like Sophiatown, Asinamali! does not 'overtly present itself as a bridge across the gap between black and white "structures of feeling" [Raymond Williams' phrase]', but rather that 'many of its internal contradictions seem to arise because it recognises and enacts the gap that exists between white and black perceptions of socio-political conditions operating in South Africa.' (1989: 189).

Asinamali! constitutes two distinct and separate racial groups through the use of various linguistic and dramatic devices. Given that $\mathrm{Zulu}$ is understood almost exclusively by African audience members, the most apparent of these devices is the retreat into the 'linguistic privacy' (Banning's phrase) of Zulu at strategic moments of the play. The songs that punctuate the narrative are the most notable example, all of which are sung in Zulu and not translated into English (the lingua franca of the play). It is worth noting that the songs are almost all politically militant and often sexually explicit.

Although the play is multilingual, the various languages are not used interchangeably or as substitutes for one another. Rather, each language is imbued with political and racial meaning. Afrikaans is constituted as the language of the oppressor - most of the officials of the state machinery represented in the play speak in Afrikaans (among other languages). The use of English is more ambivalent. At times it is constituted as the other official language of the state (for example in the 'pipi office' and court scenes), and at times it is used as a substitute for Zulu (presumably to accommodate Market Theatre audiences). Despite this, Zulu is situated in opposition to English and Afrikaans: the language of the people is set up against the language of the state.

The court scene, in which Bheki is unfairly condemned to seven years in prison for political crimes, provides an arena in which the battle of languages can play itself out. The judge speaks in Afrikaans, the interpreter translates into English for Bheki who, in turn, speaks mostly in Zulu. The onslaught of the judge's words, doubled in quantity by the translator, overwhelms the accused and the audience.

As meaning vanishes the sheer quantity of official words effectively crushes any verbal resistance and traps the victim into incomprehension and silence. Zulu and its speakers can only exist in the gaps and silences of official discourse. (Banning, 1989: 204)

The misunderstanding and confusion that arises from the rapid interchange of the three languages, as well as the humour that is derived from overliteral or mistranslation is best appreciated by those audience members who are trilingual. While the accused is rendered weak by his inability to understand Afrikaans and the subsequent barrage of words, these power relations are turned on their head for the audience members. Those who understand Zulu in addition to English 
and Afrikaans become a privileged section of the audience, united in their laughter at the slippages that occur between Zulu on the one hand and the two official languages on the other. For example, the court attempts to establish Bheki's guilt by proving that he is the father of Johannes Zulu, a political activist who has been convicted of attempting to burn the house of Mr Gasa, the councillor who informed on Msizi Dube. The dialogue runs as follows:

THAMI (judge): Is dit nie omdat Mnr Gasa vir Johannes Zulu hegtenis geneem het... nie?

BHOYI (interpreter): Was it not because Mr Gasa arrested Johannes Zulu ...?

BHEKI (accused): Yes!

THAMI: Wat jou seun is?

BHOYI: Who is your son?

BONGANI (court orderly, to the accused): Lalela inkantolo. [Listen to the court.]

THAMI: Se hy nie papa na jou nie?

BHOYI: Does he not say 'papa' to you?

BHEKI: He is my son, yes, Kodwa akuyena owesende. [But he is not my blood son.]

BONGANI: Aha!

BHOYI: He does, your worship. (Ngema, 1986: 186)

The judge can understand only the first part of Bheki's answer, that 'he is my son', and the interpreter deliberately omits to translate Bheki's qualification. Only trilingual members of the audience can comprehend the crucial nuance. Moreover, this section of the audience alone can appreciate the power that the interpreter is afforded: the judgement of the court rests on the words of this petty official. Zulu language speakers - both in the character of the interpreter and the Zulu-speaking audience members - are advantaged in this moment. Thus Ngema deftly reverses traditional power relations: those officially disempowered with regard to language enjoy a better understanding of the events.

The specific nature of the 'we' category is refined through the course of the play as the details of the lives of the five central characters accumulates. This is the category of people who suffer a litany of hardships which the various characters lament over and over again: life in the townships, rent increases, the humiliation of 'bloody fucking passbooks', work permits and v.d. offices, endless job-seeking, disenfranchisement. In other words, this is the category of black, particularly working-class, South Africans.

Racial polarization reaches a charged and confrontational climax when Bhoyi, after lambasting the audience with a tirade of 'the problems of the whole of South Africa', points to a white member of the audience, shouting, 'What is it? Hey! What is it? You, stand up. Hey mthatheni Bafana! [Go for him boys]' (Ngema, 1986: 212). 


\section{Us and them: men and women}

The issues of black oppression and resistance are at the heart of Asinamali!. Issues of sexual oppression and the problems and aspirations specific to women are not part of the subject matter of the play. The gender ideology of the play is perhaps easily eclipsed by the forceful enactment of racial and class struggle. But gender is strongly present in the languages of race and class in Asinamali!. The racial categories that the play constructs are gendered: the 'we' category excludes not only whites, but black women too.

Women in Asinamali! hold four seemingly contradictory positions: they are dependents; they are the objects of men who must be possessed for the economic or political gains that they bring; they are mothers to be exalted or despised for the children they produce; and they are a force of chaos and destruction.

French theories of femininity, using Derridian deconstruction and Lacanian psychoanalysis, can perhaps best explain how women can be seen to be playing these conflicting roles simultaneously, with no perceived contradiction. Hélène Cixous argues that the phallogocentric system of Western metaphysics is structured by a set of hierarchical and binary oppositions. The man/woman opposition, she argues, underlies a series of oppositions: subject/object; activity/passivity; culture/nature; father/mother; head/emotions; law/chaos, etc. A unified male identity is constructed in the act of relegating femininity to the negative pole of the binary opposition - male identity is the negative mirror image of female identity. Cixous argues that the consequence of this 'death-dealing binary thought' is that femininity is equated with passivity or death, leaving no positive space for women. (Cixous in Jefferson and Robey, 1986: 210)

Picking up from Cixous, Julia Kristeva argues that if patriarchy sees women as occupying a marginal position within the symbolic order, then it can construe them as the limit or borderline of that order. Women will then come to represent the necessary frontier between man and chaos, but because of their marginality they will also always seem to recede into and merge with the chaos of the outside. Because the borderline is both the shield from the chaotic wilderness and part of it, male culture can simultaneously venerate women as virginal mothers of god, and vilify them as whores or Lilith figures. ${ }^{6}$

\section{Women as dependents}

Asinamali! distinguishes, along archetypal gender lines, those who interact in the public arena from those confined to the private space of the home. Seeking employment (or alternatively earning a living through gangsterism) and engaging in political activity are established as the domain of males in the dramatic world of the play.

The three activities are integrally linked. The 'Asinamali Campaign' that Msizi Dube launches is a protest against rent increases that an impoverished and largely unemployed community cannot afford - 
that poverty and politics are inextricable issues is something that 'the whole township understood' (Ngema, 1986: 215). Solomzi joins Bra Tony in his petty gangsterism as a means of earning money. Work and theft are almost interchangeable on this level in Asinamali!. Politics and gangsterism also become associated activities. If there are two heroes in the play, then they are Msizi Dube, the political activist, and Bra Tony, the gangster. Both are valorized by the men for their courage and audacity in the face of the police. Both are a thorn in the side of the state and its various apparatus. Both are 'big names' who receive newspaper coverage and have police files. And significantly, both are murdered (and martyred) by the state. Dube is assassinated and Bra Tony is shot by troops who invade Sebokeng during a mass funeral. It would seem that the play equates political and petty criminal activity in as much as they both constitute a defiance of the laws of the state.

The three associated activities are pursued exclusively by men. Msizi Dube is 'Awu i' nsizwa amakhosi [a man among men]' (Ngema, 1986: 211) - the men who participate in political protest action. That politics is a masculine domain is corroborated by the play's numerous freedom songs that make reference to the 'boys' or the 'guys' involved in the struggle.

Gangsterism too is a world of machismo, a world in which 'good men' like Bra Tony are valorized for stealing money hidden in women's panties. The act of sexual violation is as praiseworthy as the act of theft. In fact, theft itself is a triumph of manly bravura. Bheki relates a story in which three gangsters threw him a handbag they had just snatched from a woman. The gangsters had tricked him, for looking up, he realized that he was face-to-face with 'two Big Afrikaaner policemen'.

And I said: Zinja [dogs] come! Don't run away. You've touched me. This is the day. How can you touch a lion? How can you touch a tiger? Here is the source of power! (grabbing his genital area) How can you touch me? (he starts singing his praises in Zulu)

All the prisoners jump up and go towards him and also sing his praises. They almost lift him from the floor as they shout his praises. (Ngema, 1986: 200)

Bheki becomes the prisoners' deity of masculinity for demonstrating that his sexual potency is superior to that of the police. A smart thief is a virile thief.

Employment, the third thread in the nexus of public activity represented in the play, is desperately sought by the men to meet the needs of wives and children at home. The men share the burden of bread-winning. Part of this burden is the demeaning process of seeking employment. The most offensive of the bureaucracies involved in the issuing of work permits is the v.d. office. Bongani explains that until he came to Johannesburg, no one except his 'older wife' had 'seen his man'. But after one day in the big city, 'a white boy commanded me to open my fly and show him my man' (Ngema 1986: 207). The humiliation suffered 
periphery of the dramatic world as the forces of darkness. Female sexuality threatens to erupt from the subtext and burst in from the margins of the play. The absence of women from the stage points to the play's perception of a sexual danger inherent in the female gender.

In attempting to account for women's historical absence from the stage, Sue-Ellen Case argues that by the late Middle Ages, the Church had secured the notion that immoral sexual conduct was the province of women. If the female body had become the site for sexuality, then women's performance in the public arena would elicit immoral responses from men, bringing disorder to the social body. (Case, 1988: 20) Women were consequently banned from the stage. Although by the time of Shakespeare's plays the theatre was no longer a Church-supported institution, the nature of its religious roots was still evident, if substantially transformed. The best way to alleviate the danger implicit in the female body was for males to assimilate female roles. ${ }^{7}$

Asinamali! appears to subscribe to this view. For most of the play, women are safely confined to the off-stage margins. One scene employs the dramatic technique of gender-substitute performance. Thami's re-enactment of Mrs Van Niekerk is reminiscent of pantomime in which men use caricatured gesture, movement and intonation and a falsetto voice to signal to the audience that a woman is being depicted. Even this momentary whisper from the female gender is carefully controlled by the play. As Banning points out, 'this encounter ... is tightly constrained by male discourse to marginalise and diminish it' (1989:211). The stereotypical and hyperbolic responses of the male audience on the stage guide the audience in their responses. That Thami has secured his sexual 'daily bread' is a fine accomplishment in the eyes of the interlocutors, that the provider of his daily bread is white and the boss's wife is cause for great laughter, hooting, cheering and gestures of amazement and awe.

This type of male assimilation of female roles is a visual demonstration of the distinction to be made between 'Woman' as a maleproduced fiction and historical women. Thami's vocabulary of female gesture and intonation consists quite clearly of male-originated signs. The notion and depiction of women in Asinamali! is, I have argued, derived entirely from a male point of view. And while I am not suggesting that the perspective of the gendered opposite is necessarily 'inauthentic', in the case of Asinamali! I would argue that the male portrayal of female characters is likely to remain alien to many female members of the audience. That speculation aside, the perception of female sexuality that the play presents places women firmly in a category that is other, burdensome and dangerous to men. Women are to be found on the shadowy margins of the play, in the silent negative pole of the binary opposition, outside of the 'we' and pushed into the 'you'. Women are part of the category that stands in opposition to the five central characters and the ever-diminishing section of the audience that shares their experiences. 
what she did? She pulled down her panties and Bra Tony grabbed the whole thing. A big roll of money came out man. (Ngema, 1986: 214-5)

\section{Women as mothers}

Women's procreative power is also seen as a weapon in male struggle. When the prisoners enact a political demonstration, they chant a song that pays tribute to Mrs Mandela, the mother of 'heroes', and vilifies Mrs Botha, the breeder of 'dogs' and 'armoured cars'. Neither woman is seen to play an active role in the struggle, a role in her own right. Their identities are simply that of mothers, and they are revered or despised for the offspring they produce.

Sexual activity is thus an unacknowledged weapon in the economic and political struggle. But the weapon is women and the wielders of the weapon are men. (Banning, 1989: 210)

\section{Women as the force of darkness}

In the world of the play women are dangerous. Their sexuality is anarchic and destructive. It causes men to be imprisoned. And prison, according to the song of the inmates, is a place of death:

Buti omuhle sewuzawufela ejele;

Sewuzafela ejele butu omuhle

mina nawe siboshwa sofela la.

[A handsome guy will die in jail.

Go on, you'll die in jail. Me and you

prisoner, we'll die here.] (Ngema, 1986: 1930)

Of the five prisoners in the play, three are in gaol as the result of a woman. Bheki is imprisoned because he is mistakenly identified as the father of his common-law wife's activist son after police find Bheki 'sleeping on top of a woman who you claim is your wife' (Ngema, 1986: 185).

Bongani, the stutterer, gives this explanation for his imprisonment:

Yeah! I got a girlfriend, a bitch. She fell pregnant. But there was no money to support the child. So she strangled the child in the toilet. I killed her too. And that's why I . . I . . I . . . (motions with his hand to indicate that he wants to say I am here in prison). (Ngema, 1986: 183)

Thami's story of his offence runs as follows:

I come from the Afrikaaner farm in Bloemfontein, Orange Free State. Me and my white boss' wife, Mrs Van Niekerk . . . heh, heh (indicates that they were making love). Ya, and she liked it. (183)

These three women (like all the women in Asinamali!) have no physical presence on a stage occupied exclusively by men. They exist on the 
in the 'pipi office' is metonymic for the experiences of job-hunting, subsequent employment by abusive bosses, and frequent interaction with the web of intransigent state bureaucracies: it insults one's 'manhood'.

Women remain in the private sphere of the home. There they become a burden to the men. They interfere with the lives the men lead in the public arena. The first reference to a woman in Asinamali! is to 'a girlfriend, a bitch' - Bongani's girlfriend whom he killed after she strangled their baby because 'there was no money to support [it]' (Ngema, 1986:185). Bongani's words reveal the men's perception of women's identity: women are girlfriends, wives or mothers. What's more, the two categories of women - girlfriend and bitch - are identical to each other, synonymous, for Bongani, and the play never challenges his perception. Moreover, that Bongani has no sympathy for a woman who feels compelled to kill her child because she is poverty-stricken is the dominant sensibility in the world of the play. 'Bitch' is a resonant term of abuse in Asinamali!. One of the most despised characters of whom the men speak is Sergeant Schoeman, the warder who forces female prisoners to have sexual intercourse with him. In a moment of great anger, Bheki describes Schoeman as a 'bitch', confirming that a term of abuse traditionally reserved for women is the worst insult that can be evoked.

\section{Women as political and economic weapons}

Banning incisively articulates the role women play in Asinamali! as the providers of the means of economic and political power in a male struggle:

Bheki's woman pays the train fares and her house in Lamontville enables
him to become a 'boss in a dead man's home'. . . The women prisoners are
the means by which the Sergeant can find his own sexual gratification and
demonstrate his power over the male prisoners. His sexual abuse of 'their'
women enacts his abuse of his officially sanctioned power over them.
Their sexual deprivation exemplifies their political impotence (1989:210).

Similarly, Thami's highest pleasure in his sexual relationship with Mrs Van Niekerk lies in the victory that it constitutes over his racial and class enemy - Mr Van Niekerk. Solomzi relates a story to his fellow prisoners, the subtext of which literally identifies female sexuality with money. In his story, Solomzi and his gangster friend, Bra Tony, meet an (unnamed) Indian woman at Verulem Station. Since she is 'very pretty', Solomzi starts to talk to her. Bra Tony, however, interrupts his friend's seduction attempt in order to rob the woman of her money:

'Give me your panties' [Bra Tony demands of the woman]. She said: 'I'm having my period.' 'My baby, my sweetheart, give it to me.' You know 


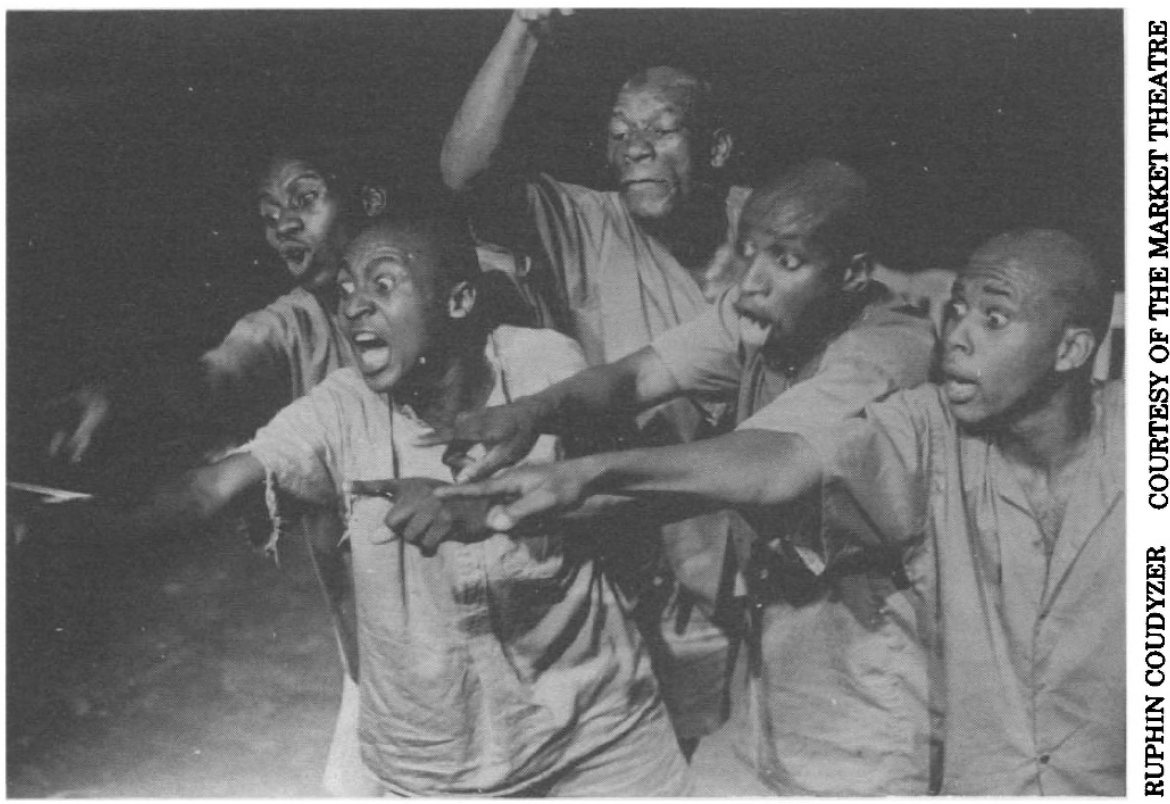

The collectivity of the men is accentuated by the stylistic and visual qualities of the play.

\section{The gender of form}

The bond of brotherhood and shared experience is accentuated by the stylistic qualities of the play. The language of the actors is partially sung, partially chanted, and is almost rhymed; they dance and gyrate with a beauty and a frenzied energy and create a compelling aesthetic of sweat. Much of the language, sound and song takes the form of choral verse. The actors chant lines together; one voice shouts out a slogan and the other four respond; one actor speaks while the others sing or hum in the background; they sing most of the songs collectively; and when telling a story they create a barrage of voices that rapidly succeed one another so that it is difficult to distinguish which actor's voice is being heard and whose story is being told. The five bodies and voices merge into one creating the effect of a collective being and a collective experience of suffering, anger, amusement and resistance.

The unity of the group is reinforced on a visual level. The actors are often situated in a row in which they rock, sway and dance in unison. Repetition of action is also used to enhance the sense of group experience. When one of the actors tells of the medical examination to which he was subjected during the process of obtaining a work permit, for example, the actors queue up and successively re-enact the ritual whereby the genitals are examined. This leads to a visual representation of the strong emotional connexion between the players. When Solomzi is mourning over the recollected death of his friend Bra Tony, 
for example, the others mourn with him, sharing and expressing in song and movement his own pain. Similarly when one man is celebrating a joyous memory, the others jump up and down and hug each other like little boys sharing a moment of delight. Stylistically and visually, women stand outside of the collective, the enmeshed team of brothers fighting a hostile world.

\section{Conclusion}

The battle of the sexes plays itself out within and beneath the struggle for racial and class liberation in Asinamali!. Class, race and gender meanings reciprocally constitute each other. It is a sad irony that the discourses of the gaolers and the gaoled - the oppressors and the oppressed-converge on one major issue: women. For both camps, women must be contained and marginalized. Asinamali!, in failing to consider gender ideology, reinforces the dominant ideology which deems women a threat to the most fundamental order - the rudimentary social matrix, civilization itself, that which makes the social possible. Female sexuality embodies chaos and danger; their primary usefulness is in the political or economic power they can afford to men. Thus the resistance discourse of the prisoners reinforces, in crucial respects, the dominant discourse it despises.

Msizi Dube's political leadership and violent death inspired, in the words of the preface to the play:

a group of 'committed artists' whose primary goal was the revelation and ultimate eradication of racial and social inequality in South Africa. Out of this concern Mbongeni Ngema's Asinamali! was born. (Ngema, 1986: 179).

The process of revelation or education is primarily directed at those who do not suffer the inequality - the 'them' category. The 'we' category, on the other hand, is called to action, to understand and eradicate their oppression. In constructing the 'we' category, Asinamali! binds a section of the audience into an ideological unity. The sheer energy of the players pushes the dramatic world on to the edges of the world outside the play, urging its brothers in the audience to act now. 'Go for him boys.' But what of the women, those who suffer the inequalities that the play represents, and more? They are excluded from the brotherhood of freedom fighters who are bound together by their struggle against apartheid, and swept up by the mobilizatory force of the play. The gender ideology of Asinamali! undermines its primary imperative. 


\section{Notes}

Carol Steinberg is a lecturer in the Department of Dramatic Art, University of the Witwatersrand, Johannesburg. She is an executive member of the Performing Arts Workers Equity (PAWE), a nonracial organization committed to the education of theatre workers and to the improvement of their conditions of work.

The photographs are of different casts of Asinamali!

1 See Steadman (1990) for a more detailed categorization of anti-apartheid theatre.

2 I am referring to Albie Sachs's paper 'Preparing Ourselves for Freedom' which can be found in de Kok and Press (1990).

3 Mbongeni Ngema is a leading black South African playwright, director and producer. His company, Committed Artists, created the musicals Sarafina and Township Fever, which have both received international acclaim.

4 An analysis of the political implications of the play's racial categorization lies outside of the scope of this paper.

5 The Market Theatre, established in 1976, is the key institution in South Africa that provided the material conditions for local, often anti-apartheid, companies to produce their work at a time when state repression was often severe.

6 See Jefferson and Robey (1986: 209-21).

7 For a detailed version of this argument see Case (1988: 5-28).

\section{References}

BANNING, Y. (1989) 'English Language Usage in South African Theatre Since 1976' unpublished Masters thesis.

BARRETT, M. (1984) Women's Oppression Today London: Verso.

CASE, S. (1988) Feminism and Theatre London: Macmillan.

DE KOK, I. and PRESS, K. (1990) Spring is Rebellious Cape Town: Bachu Books.

GREENE, G. and KAHN, C. (1985) editors, Making a Difference London and New York: Methuen.

JEFFERSON, A. and ROBEY, D. (1986) Modern Literary Theory: A Comparative Introduction London: Batsford.

NDLOVU, D. (1986) Woza Afrika! New York: George Braziller.

NEWTON, J. and ROSENFELT, D. (1985) editors, Feminist Criticism and Social Change New York and London: Methuen.

NGEMA, M. (1986) 'Asinamali!' in NDLOVU (1986).

STEADMAN, I. (1990) 'Theatre Beyond Apartheid' unpublished inaugural lecture. WEEDON, C. (1988) Feminist Practice and Poststructuralist Theory Oxford and New York: Basil Blackwell. 